\title{
PSYCHOLOGICAL WELL BEING PADA ANAK BERKEBUTUHAN KHUSUS DI SEKOLAH INKLUSIF
}

\author{
Komarudin \\ Universitas 'Aisyiyah Yogyakarta, Indonesia \\ komarudin_psi@unisayogya.ac.id
}

\begin{abstract}
This study aims to determine the dynamics of the psychological well-being in childrens with special needs in inclusive schools and the factors that affect the psychological well being in children with special needs in inclusive schools. Data collection in this study was conducted using semi-structured interview techniques. Analysis of the data used refers to the opinions of Miles and Hubermen through 3 steps, namely data reduction, data display, and conclusion drawing. The results showed that: 1) The four research subjects had independence in carrying out daily activities and had good environmental control; 2) In determining the purpose of life, the four subjects have had their dreams, but have not been able to direct them; 3) The positive relationship of the subject to others, is influenced by the response of others to the subject. If the environment conducts bullying actions on the subject, then the subject feels threatened to be in the environment; 4) Factors that affect psycological well being subjects in inclusive schools, namely economic, social, learning systems, and subject characteristics.
\end{abstract}

Keywords; psychological well-being, children with special needs, inclusive schools.

\begin{abstract}
Abstrak
Penelitian ini bertujuan untuk mengetahui dinamika psychological well being pada anak berkebutuhan khusus di sekolah inklusif dan faktor-faktor yang mempengaruhi psychological well-being pada anak berkebutuhan khusus di sekolah inklusif. Pengumpulan data dalam penelitian ini dilakukan dengan menggunakan teknik wawancara semi terstruktur. Analisis data yang digunakan mengacu pada pendapat Miles dan Hubermen melalui 3 langkah, yaitu data reduction, data display, dan conclusion drawing. Hasil penelitian menunjukkan bahwa: 1) Keempat subjek penelitian memiliki kemandirian dalam melakukan aktifitas sehari-hari dan memiliki penguasaan lingkungan yang baik; 2) Dalam menentukan tujuan hidup, keempat subjek telah memiliki cita-cita, akan tetapi belum mampu untuk mengarahkannya; 3) Hubungan positif subjek dengan oranglain, dipengaruhi oleh respon oranglain kepada subjek. Apabila lingkungan melakukan tindakan bullying terhadap subjek, maka subjek merasa terancam berada di lingkungan tersebut; 4) Faktor yang mempengaruhi psychological well-being subjek di sekolah inklusif, yaitu ekonomi, sosial, sistem pembalajaran, dan karakteristik subjek.
\end{abstract}

Kata kunci; psychological well-being, Anak Berkebutuhan Khusus, Sekolah Inklusif. 


\section{Pendahuluan}

Kebahagiaan adalah hal yang didambakan setiap manusia, tanpa terkecuali bagi Anak Berkebutuhan Khusus (ABK). Dalam hal ini, ABK yang dimaksud adalah anak yang memiliki gangguan fungsi yang berlangsung lama dan menyebabkan terbatasnya partisipasi di masyarakat.

Hal ini sesuai dengan kesepakatan negara-negara di dunia dalam convention on the right of person with disabilities tahun 2017 di New York, Amerika Serikat, bahwa disabilitas/ ABK adalah orang yang memiliki keterbatasan fisik, mental, intelektual atau sensorik dalam jangka waktu lama yang dalam berinteraksi dengan lingkungan dapat menemui hambatan yang menyulitkan untuk berpartisipasi penuh dan efektif. (www.bps.go.id, 2017).

Seiring berkembangnya Hak Asasi Manusia, ABK juga memiliki hak yang sama dalam setiap aspek kehidupan termasuk dalam memperoleh pendidikan. Hal ini ditandai dengan adanya perubahan sistem pendidikan dari segregasi, integrasi, menuju ke dalam sistem pendidikan inklusif. Di sekolah inklusif, sekolah memberikan kesempatan bagi semua peserta didik yang normal ataupun memiliki kebutuhan khusus untuk mengikuti pendidikan atau pembelajaran dalam satu lingkungan pendidikan secara bersama-sama. Sekolah yang inklusif juga menghargai keragaman dalam kemampuan, budaya, ras, suku, atau latar belakang sosial (Mangunsong, 2009). Saat ini, dari 1,6 juta $A B K$ di Indonesia, sekitar 299 ribu telah sekolah di sekolah regular/inklusif dan 115 ribu sekolah di SLB. Banyaknya $\mathrm{ABK}$ yang mengenyam pendidikan di sekolah inklusif dibandingkan dengan SLB menunjukkan masyarakat Indonesia telah menerima sistem pendidikan inklusif tersebut. (kemendikbud.go.id, 2017).

Dalam Permendiknas RI No. 70 tahun 2009 disebutkan bahwa salah satu tujuan mulia ditumbuhkannya sekolah inklusif di Indonesia adalah untuk mewujudkan penyelenggaraan pendidikan yang menghargai keanekaragaman dan tidak diskriminatif bagi semua peserta didik.

Selain itu Kustawan (2013) menambahkan bahwa di sekolah inklusif siswa berkebutuhan khusus maupun siswa regular dapat secara bersama-sama mengembangkan potensi masing-masing dan mampu untuk dapat hidup berdampingan secara harmonis.

Siswa berkebutuhan khusus yang mampu mengembangkan potensi dan dapat belajar secara berdampingan dengan siswa regular di sekolah inklusif berarti siswa tersebut telah mendapatkan 
dukungan sosial dari lingkungan sekolah. Menurut Jibeen dan Khalid, (2010), semakin tinggi dukungan sosial, maka semakin baik kesejahteraan psikologis/ psychological well-being yang dirasakan. Artinya ABK yang mampu hidup berdampingan secara harmonis dengan siswa regular di sekolah inklusif, maka diasumsikan psychological well being yang dirasakan tinggi.

Akan tetapi, studi pendahuluan yang dilakukan peneliti pada tahun 2015 di salah satu sekolah inklusif di kabupaten Bantul menunjukan bahwa ABK masih dilayani seperti siswa reguler dengan kurikulum dan program yang sama tanpa adanya program pembelajaran individual, sehingga ABK tidak mampu mengikuti materi pelajaran.

Guru kelas dan guru mata pelajaran yang notabenenya berlatar belakang pendidikan umum masih memiliki pengetahuan yang terbatas untuk menangani ABK selama proses belajar mengajar di kelas, sehingga fokus mengajar lebih pada siswa normal / reguler dan ketercapaian target materi pelajaran, serta bergantung pada Guru Pembimbing Khusus (GPK) dalam pendampingan $\mathrm{ABK}$, padahal GPK hanya memiliki waktu 2 kali dalam 1 minggu bertugas di sekolah inklusif. Di sisi lain, peran orangtua siswa dalam menjalin komunikasi dengan pihak sekolah juga masih rendah. Sebagian besar orangtua dari ABK hanya datang ke sekolah ketika mendapatkan undangan pengambilan beasiswa bagi anaknya. Bahkan ada orangtua yang masih malu anaknya masuk dalam kategori ABK karena berpersepsi bahwa ABK itu adalah anak yang cacat.

Hasil penelitian lain yang dilakukan oleh Ribbany (2016) juga menunjukkan bahwa ada tindakan bullying yang terjadi pada ABK di salah satu sekolah inklusif di kota Sidoarjo, Jawa Timur. Siswa regular melakukan bullying terhadap siswa yang berkebutuhan khusus ketika berada di sekolah, baik di dalam kelas ataupun saat diluar kelas, serta ketika pada saat jam pelajaran maupun pada saat jam istirahat berlangsung.

Bentuk bullying tersebut berupa kontak verbal langsung (mengancam, mempermalukan, merendahkan, mengganggu, sarkasme, mencela dan mengejek, mengintimidasi, memaki, menyebarkan gosip, pemerasan), perilaku non-verbal langsung (melihat dengan sinis, menampilkan ekspresi muka yang merendahkan, menjahili), perilaku non verbal tidak langsung (mendiamkan, mengucilkan, mengirim surat kaleng), kontak fisik (memukul, mendorong, menjambak, mencubit, mencakar, menendang). 
Fakta ini menunjukkan kurangnya dukungan sosial dari guru dan siswa regular terhadap ABK di sekolah inklusif diprediksikan akan berdampak pada ABK tersebut. Sekolah merupakan lingkungan kedua yang paling banyak berpengaruh di samping lingkungan keluarga. Interaksi antara guru dan teman teman di sekolah akan berpengaruh terhadap anak yang bersangkutan (Somantri, 2007).

Kurangnya dukungan disekolah, diasumsikan ABK akan memiliki psychological well being yang rendah. Hal ini didasarkan pada pendapat Jibeen dan Khalid (2010), bahwa rendahnya dukungan sosial mengindikasikan tingginya tekanan psikologis yang dialami seseorang, sehingga mengakibatkan kesejahteraan psikologinya juga rendah.

Menilik dari uraian di atas, kesejahteraan psikologis/ psychological well-being merupakan hal penting bagi $\mathrm{ABK}$ untuk menerima kekuatan dan kelemahan diri apa adanya (sel-facceptance), memiliki tujuan hidup yang bermakna (purpose in life), mengembangkan hubungan yang positif dengan orang lain (positive relationship with others), menjadi pribadi yang mandiri (autonomy), memiliki akses yang memadai akan sumber-sumber kehidupan (environmental mastery), serta mampu mengendalikan diri dengan lingkungan dan terus berkembang secara personal (personal growth). Adanya permasalahanpermasalahan ABK di sekolah inklusif, mendorong peneliti untuk mengkaji lebih jauh deskripsi psychological well-being pada $\mathrm{ABK}$ yang mengenyam pendidikan di sekolah inklusif.

Berangkat dari hal tersebut, maka pertanyaan penelitian yang diajukan dalam penelitian ini, yaitu 1) Bagaimanakah dinamika psychological well being pada anak berkebutuhan khusus di sekolah inklusif?; 2) Faktor-faktor apa sajakah yang mempengaruhi psychological well being pada anak berkebutuhan khusus di sekolah inklusif?

\section{Metode Penelitian}

Penelitian ini menggunakan pendekatan kualitatif karena penelitian ini berusaha menjawab pertanyaan penelitian yang bersifat eksploratif dan mendalam, yaitu menggali untuk mendapatkan pemahaman yang menyeluruh mengenai dinamika psychological well-being dari sudut pandang responden dan mengeksplorasi faktor-faktor yang dapat mempengaruhi dinamika psychological well-being pada para responden.

Fokus penelitian ini adalah psychological well-being, yaitu pencapaian utuh dari potensi psikologis seseorang dan suatu 
keadaan di mana seseorang tersebut dapat menerima kekuatan dan kelemahan diri apa adanya, memiliki tujuan hidup yang bermakna, mengembangkan hubungan yang positif dengan orang lain, menjadi pribadi yang mandiri, memiliki akses yang memadai akan sumber-sumber kehidupan, dan mampu mengendalikan diri dengan lingkungan dan terus berkembang secara personal.

Pengambilan sampel pada penelitian ini dilakukan dengan teknik purposive sampling, yaitu teknik pengambilan sampel didasarkan pada pertimbangan tertentu (Sugiyono, 2012). Sampel atau yang sering disebut juga sebagai responden dalam penelitian ini mengacu pada konsep teoretis mengenai psychological well being dan Anak Berkebutuhan Khusus. Adapun karakteristik responden dalam penelitian ini adalah sebagai berikut:

1. Anak yang masuk dalam kategori Anak Berkebutuhan Khusus (ABK)

ABK yang dipilih dalam penelitian ini adalah anak yang masuk dalam salah satu kategorisasi ABK yang ditinjau dari sudut pandang psikologi dan layanan pendidikan yang dikemukakan Mangunsong (2009), yaitu: tunanetra, tunarungu-wicara, tunagrahita, tunadaksa, tunalaras, autis, tunaganda, ADHD, gangguan belajar spesifik, CIBI, indigo, dan anak kurang beruntung.

2. Bersekolah di sekolah inklusif Dipilihnya ABK yang mengenyam pendidikan di sekolah inklusif sebagai responden dalam penelitian ini karena berdasarkan studi pendahuluan, ditemukan fakta bahwa ABK di sekolah inklusif di Indonesia masih rentan mendapatkan perlakuan diskriminatif dari guru dan bulliying dari siswa lain yang normal.

Pengumpulan data dalam penelitian ini dilakukan dengan menggunakan teknik wawancara semi terstruktur yang bertujuan untuk menemukan permasalahan secara lebih terbuka, yaitu dinamika psychological wel-being pada masingmasing responden yang bersifat subjektif karena mengacu pada konsep dan deskripsi tiap responden yang berbeda antara satu responden dengan responden lain. Dalam penelitian semi terstruktur ini, peneliti membuat panduan wawancara yang dikembangkan dari pertanyaan-pertanyaan penelitian, yaitu: bagaimanakah dinamika psychological well-being dan faktor-faktor apa sajakah yang mempengaruhi psychological wellbeing pada Anak Berkebutuhan Khusus di sekolah inklusif. Adapun pedoman wawancara dalam 
penelitian ini adalah sebagai berikut:

1. Dimensi psychological well being Pertanyaan yang akan diajukan mengarah pada 6 dimensi psychological well being yang dikemukakan oleh Ryff dan Singer (2008), yaitu penerimaan diri (self-acceptance), tujuan hidup (purpose in life), pertumbuhan diri (personal growth), otonomi (autonomy), penguasaan lingkungan (environmental mastery) dan hubungan positif dengan orang lain (positive relations with other).

2. Faktor-faktor yang Mempengaruhi psychological well-being. Faktor psychological well being yang akan digali dalam penelitian ini berdasarkan pendapat Conger, dkk (2002), yaitu faktor ekonomi, demografis, dan sosial dari ABK.

Selain wawancara dengan responden, penelitian ini nantinya menggunakan data yang bersumber dari significant others para responden seperti guru BK dan wali kelas. Hal ini dimaksudkan untuk melakukan cross check data yang bersumber dari keterangan para responden, yaitu mencoba menggali keterangan dari orang-orang yang berada di sekitar responden, sehingga mendapatkan data yang valid.

\section{Hasil dan Pembahasan}

Dinamika psychological wellbeing pada Anak Berkebutuhan Khusus di sekolah inklusif dapat dilihat dari 6 dimensi psychological well being berikut ini:

1. Penerimaan diri (self-acceptance). Keempat subjek tampak belum bisa menerima dirinya dan masih berkutat pada kekurangan yang dimilikinya. Misalnya Li masih merasa malu dengan kecacatan fisik yang dimiliki; Dc masih belum bisa menerima kekurangan yang dimiliki, sering susah konsentrasi dalam hal belajar dan kecewa belum pernah diikutkan lomba oleh pihak sekolah. Sementara itu Al dan Ma belum mampu memahami dirinya, termasuk kekurangan dan kelebihan, sehingga belum bisa menunjukkan sikap positif terhadap lingkungan. Ryff dan Singer (2008) mendefinisikan penerimaan diri sebagai sikap yang positif untuk menerima kelebihan ataupun kekurangan serta terhadap kehidupan masa lalu. Mengacu kepada jawaban dari keempat subjek tersebut dapat digambarkan bahwa subjek belum memiliki penerimaan diri yang baik dan masih merasa kecewa terhadap kondisi fisik dan peristiwa masa lalu (bullying) yang pernah dialami. 
2. Tujuan Hidup (Purpose in Life).

Keempat subjek menyatakan memiliki impian ataupun cita cita di masa depan. Akan tetapi 3 subjek menyatakan belum memahami bagaimana mewujudkan cita - cita tersebut. Li masih malu dengan kecacatan fisik untuk menjadi profesi mandor dan $\mathrm{Al}$ juga bingung bagaimana cara mewujudkan mimpi jadi pengrajin gerabah. Sementara itu Ma sudah memutuskan untuk jadi seorang arsitek karena melihat sosok ayahnya sebagai supplier bahan bangunan, sehingga menginspirasinya untuk menjadi arsitek. Ryff dan Singer (2008) memaknai tujuan hidup sebagai suatu kemampuan sesorang mengarahkan hidupnya menjadi bermakna. Berdasarkan hasil wawancara, maka keempat subjek tersebut telah memiliki rencana untuk tujuan hidupnya akan tetapi masih belum mampu mengarahkannya dalam mewujudkan tujuan hidupnya.

3. Hubungan positif dengan orang lain (positive relationship with others)

Hubungan positif subjek dengan oranglain atau lingkungannya berbeda-beda. Ma dan Dc cukup nyaman berada di lingkungan sekolah karena guru baik kepada keduanya lantaran memperlakukannya dengan baik dan tidak membeda bedakan. Sementara Li dan Al merasa guru galak dan teman di sekolah sering melakukan bullying terhadap keduanya yang menjadikannya bereakasi dengan melakukan tindakan fisik seperti memukul meja dan melempar kursi Ryff dan Singer (2008) menganggap bahwa individu yang memiliki hubungan positif, yaitu individu tersebut mampu mengembangkan hubungan yang positif, ramah, dan hangat dengan orang lain. Mengacu pada kondisi keempat subjek tersebut menunjukkan bahwa respon lingkungan terhadap keempat subjek tersebut juga mempengaruhi interaksi subjek terhadap lingkungan sebayanya.

4. Kemandirian (Autonomy).

Dalam activity daily living (makan, minum, mandi, BAK, $\mathrm{BAB})$, keempat responden dapat melakukannya sendiri tanpa bantuan. Akan tetapi untuk aksesibilitas ke sekolah, keempat responden masih diantar jemput oleh orangtua ataupun dengan bantuan oranglain. Sementara itu untuk kegiatan belajar di sekolah, keempat responden belum mampu mandiri. Sebenarnya keempatnya membutuhkan Guru Pendamping Khusus, akan tetapi tidak selalu ada untuk mendampingi dalam proses 
belajar di kelas. Di rumahpun keempat subjek tampak kurang pendampingan, sehingga sering tidak mengerjakan PR atau mengerjakan PR tapi yang mengerjakan adalah guru les nya. Menurut Ryff dan Singer (2008), orang yang memiliki kemandirian yang tinggi adalah orang yang independen dan menentukan diri sendiri, dapat bertahan menghadapi tekanan sosial baik dalam tindakan maupun pikiran, mampu mengatur perilaku diri sendiri, mengevaluasi diri dengan standard pribadi. Mengacu pada keadaan keempat responden tersebut menunjukkan bahwa keempat responden belum memiliki kemandirian secara penuh terutama dalam hal belajar.

5. Penguasaan Lingkungan (Enviromental Mastery).

Ryff \& Singer (2008) menyatakan bahwa penguasaan lingkungan berarti individu memiliki akses yang memadai akan sumbersumber kehidupan. Orang yang memiliki penguasaan lingkungan yang tinggi adalah orang yang merasa memiliki kemampuan untuk menguasai dan mengatur lingkungan, mengontrol hal-hal kompleks dalam berbagai aktivitas, efektif dalam menggunakan kesempatan yang ada dilingkungan, dapat memilih atau membuat konteks yang sesuai dengan nilai atau kebutuhan pribadinya. Dalam hal ini, keempat subjek memiliki kemampuan untuk menguasai aksesibilitas dan mobilitas di lingkungan sekolah dengan baik.

6. Pertumbuhan Pribadi (Personal Growth)

Keempat subjek tampak belum memiliki pertumbuhan pribadi secara optimal dan masih berkutat pada kelemahan baik fisik maupun mental yang dimiliki. Ryff dan Singer (2008) mengemukakan bahwa orang dengan pertumbuhan pribadi adalah orang yang merasa terus mengalami perkembangan, melihat dirinya sedang mengalami pertumbuhan dan perkembangan, terbuka pada pengalaman baru, merasa mengetahui potensi dirinya, melihat adanya peningkatan diri dan perilaku dari waktu ke waktu, mengalami perubahan yang merefleksikan pengetahuan diri danefektifitas. Kebutuhan akan pentingnya memiliki dan mengembangkan potensi belum disadari oleh ketiga subjek.

Dalam penelitian ini ditemukan faktor-faktor yang mempengaruhi psychological wellbeing pada subjek penelitian (anak berkebutuhan khusus) di sekolah inklusif, antara lain: 
1. Sosial

Sosial ini berhubungan dengan dukungan lingkungan sekolah saat proses pembelajaran pada diri Anak Berkebutuhan Khusus (ABK). ABK akan mengalami kesulitan dalam mengikuti proses pembelajaran di sekolah inklusi apabila tidak di damping secara rutin oleh tenaga yang ahli dalam bidang penanganan ABK

2. Ekonomi

Penghasilan ekonomi yang rendah juga mengakibatkan ABK tidak nyaman disaat orangtuanya belum mampu bayar SPP. Selain itu keadaan ekonomi yang lemah juga menjadikan orangtua tidak mampu menyediakan Guru Pendamping Khusus secara mandiri.

3. Sistem Pembelajaran

Sistem pembelajaran yang disamakan dengan kelas regular tanpa modifikasi akan menyulitkan ABK dalam mengikuti proses pembelajaran, meskipun standar penilaian telah diturunkan dari siswa normal.

4. Karakteristik

Karakteristik atau kategorisasi dari ABK yang berbeda juga mempengaruhi kesejahteraan psychologisnya. Keterbatasan keterbatasan yang dapat dilihat (fisik dan perilaku unik) menjadikan ABK akan mudah mendapatkan tindakan bullying dari lingkungannya. Sementara itu keterbatasan yang tidak terlihat oleh mata dan memerlukan pengetesan lebih lanjut (mental), tidak memancing lingkungan untuk melakukan bullying.

\section{Simpulan dan Saran}

Simpulan

Mengacu pada hasil dan pembahasan, dapat disimpulkan bahwa:

1. Keempat subjek penelitian memiliki kemandirian dalam hal activity daily living dan penguasaan lingkungan yang baik. Hal ini menjadikan subjek mampu melakukan aktivitas keseharian secara mandiri dan juga melakukan orientasi dan mobilitas di lingkungan sekolah.

2. Dalam menentukan tujuan hidup, sebenarnya keempat subjek telah memiliki cita -cita, akan tetapi belum mampu untuk mengarahkannya. Hal ini dikarenakan subjek tampak belum memiliki penerimaan dari yang baik dan masih berkutat pada kekurangan (fisik dan nonfisik) yang dimilikinya. Belum adanya penerimaan diri ini juga mengakibatkan subjek belum memiliki pertumbuhan pribadi secara optimal.

3. Hubungan positif subjek dengan oranglain, dipengaruhi oleh respon oranglain terhadap kepada subjek. Apabila 
lingkungan melakukan tindakan bullying terhadap subjek, maka subjek merasa terancam berada di lingkungan tersebut. Sebaliknya, apabila lingkungan memperlakukan subjek seperti anak "normal", maka subjek juga merasa nyaman dan dapat menjalin relasi dengan baik.

4. Faktor yang mempengaruhi psycological well being subjek di sekolah inklusif, yaitu ekonomi, sosial, sistem pembalajaran, dan karakteristik subjek.

\section{Saran}

Berdasarkan hasil penelitian dan informasi yang diperoleh, maka peneliti dapat memberikan saran sebagai berikut:

1. Bagi Subjek

Dalam mencapai psychological well being, hendaknya subjek mampu menerima kelebihan dan kekurangan dirinya sehingga pertumbuhan pribadi dapat berlangsung secara optimal

2. Bagi Sekolah

Sekolah hendaknya menciptakan lingkungan yang kondusif bagi ABK, misalnya lingkungan yang bebas dari bullying dan sistem pembelajaran yang disesuaikan dengan karakteristik masingmasing ABK

3. Bagi Peneliti Selanjutnya

Peneliti selalnjutnya dapat mempertimbangkan karakteristik subjek yang sejenis untuk dapat mengetahui secara lengkap profil psychological well being pada diri subjek berdasarkan kategorisasi ABK.

\section{Daftar Pustaka}

Alsa, A. (2004). Pendekatan

Kuantitatif dan Kualitatif serta

Kombinasinya dalam Penelitian

Psikologi. Yogyakarta: Pustaka

Pelajar.

BPS. (2017, Agust 3). BPS Dukung

Hak Penyandang Disabilitas.

Diunduh dari

https://www.bps.go.id/index.php/k

egiatanLain/91.

Conger, R.D., Wallace, L.E., Sun, Y., Simon, R.L., McLoyd, V.C., Brody, G. H. (2002). Economic Pressure in African American Families: A Replication and Extension of the Family Stress Model. Journal of Development Psychology, 38, 179-193.

Diener, E., Wirtz, D., BiswasDiener, R., Tov, W., Kim-Prieto, Chu, Choi, Dong-won, \& Oishi, S. (2009). New measures of well-being. E. Diener (ed.), Assessing well-being: The collected works of Ed Diener, Social Indicators Research Series 39, doi: 10.1007/978-90-481-2354412.

Halahan, D.P \& Kauffman, J.M. (2006). Exeptional Childern: Introduction to Special Education (International, ed). Allyn \& Bacon: Boston. 
Huppert, F. A. 2009. Psychological

Well-being: Evidence

Regarding its Causes and

Consequences. Journal

Compilation of Applied

Psychology: Health and Well-

being, 1, 137-164.

Jibeen, T., \& Khalid, T. (2010).

Predictors of psychological

well-being of Pakistani

immigrants in Toronto,

Canada. International Journal of

intercultural relation, 34, 452-464.

Keyes, C. L. (2013). Mental Well

Being: International Contributions

to The Study of Positive Mental

Health. Atlanta: Springer.

Kustawan, D. (2013). Pendidikan

Inklusif dan Upaya

Implementasinya. Jakarta: PT.

Luxima Metro Media.

Mangungsong, F. (2009).Psikologi

dan Pendidikan Anak

Berkebutuhan Khusus: Jilid kesatu. Jakarta: LP3PS UI

Mangungsong, F. (2011).Psikologi

dan Pendidikan Anak

Berkebutuhan Khusus: Jilid kedua.

Jakarta: LP3PS UI

Maulana, M. (2008). Anak Autis:

Mendidik Anak Autis dan

Gangguan Mental Lain Menuju

Anak Cerdas dan

Sehat.Yogyakarta: Ar-Ruzz

Media

Nelma H., Bintari D. R, Nurwiyanti

F. (2012). Hubungan Komitmen

Beragama Dengan Kesejahteraan

Psikologis Pada Masyarakat

Jakarta Usia Dewasa. Jurnal

Pitutur. 1, 25 -56
Ninawati, F.I. (2005). Gambaran

Kesejahteraan Psikologis Pada

Dewasa Muda Ditinjau Dari

Pola Attachment. Jurnal

Psikologi, 3, 44-64.

Rahma RN. 2015. Kesejahteraan

Psikologis Penyandang

Tunanetra (Studi pada

Mahasiswa Tunanetra Fakultas

Ilmu Pendidikan Universitas

Negeri Yogyakarta). Jurnal

Bimbingan dan Konseling, 7, 1-13

Ribbany, E.T. (2016). Bullying Pada

Pola Interaksi Anak

Berkebutuhan Khusus (ABK) di

Sekolah Inklusif. Jurnal

Paradigma, 4, 1 - 7 .

Ryan, R. M., \& Deci, E. L. (2001).

Onhappiness and human

potensials: areview of research

on hedonic and eudaimonic

well being. Annual Review, 141-

66.

Ryff, C.D., \& Singer, B.H. (2008).

Know Thyself and Become

What You Are: An Eudaimonic

Approach to Psychological

Well-being. Journal of Happiness

Studies 9,13-39.

Smith, J.D. (2012). Sekolah Inklusif:

Konsep dan Penerapan

Pembelajaran. Bandung: Nuansa

Winarsih, T. (2006). Subjective wellbeing pada wanita menopause. Skripsi. Yogyakarta: Fakultas Psikologi Universitas Gadjah Mada. (Tidak Diterbitkan). 